\title{
Blood Serum From Head and Neck Squamous Cell Carcinoma Patients Induces Altered MicroRNA and Target Gene Expression Profile in Treated Cells
}

OPEN ACCESS

Edited by:

Dietmar Thurnher,

Medizinische Universität

Graz, Austria

Reviewed by:

Roger Victor Moukarbel,

American University of Beirut,

Lebanon

Thorsten Fuereder,

Medizinische Universität

Wien, Austria

${ }^{*}$ Correspondence:

Michal M. Masternak michal.masternak@ucf.edu

Specialty section: This article was submitted to Head and Neck Cancer, a section of the journal

Frontiers in Oncology

Received: 27 February 2018 Accepted: 25 May 2018

Published: 11 June 2018

Citation:

Allen B, Schneider A, Victoria B, Nunez Lopez YO, Muller M,

Szewczyk M, Pazdrowski J,

Majchrzak E, Barczak W,

Golusinski W, Golusinski P and Masternak MM (2018) Blood Serum From Head and Neck Squamous Cell Carcinoma Patients Induces Altered MicroRNA and Target Gene Expression Profile in Treated Cells.

Front. Oncol. 8:217.

doi: 10.3389/fonc.2018.00217
Brittany Allen', Augusto Schneider', Berta Victoria', Yury O. Nunez Lopez ${ }^{3}$, Mark Muller', Mateusz Szewczyk ${ }^{5}$, Jakub Pazdrowski ${ }^{5}$, Ewa Majchrzak', Wojciech Barczak', Wojciech Golusinski ${ }^{5}$, Pawel Golusinski, ${ }^{5,6}$ and Michal M. Masternak ${ }^{1,5 *}$

${ }^{1}$ Burnett School of Biomedical Sciences, College of Medicine, University of Central Florida, Orlando, FL, United States, ${ }^{2}$ Faculdade de Nutrição, Universidade Federal de Pelotas, Pelotas, Brazil, ${ }^{3}$ Translational Research Institute for Metabolism and Diabetes, Florida Hospital, Orlando, FL, United States, ${ }^{4}$ Epigenetics Division, TopoGEN Inc, Buena Vista, CO, United States, ${ }^{5}$ Department of Head and Neck Surgery, Poznań University of Medical Sciences, The Greater Poland Cancer Centre, Poznan, Poland, ${ }^{6}$ Biology and Environmental Studies, Head and Neck Cancer Biology Laboratory, Poznań University of Medical Sciences, Poznan, Poland

The head and neck squamous cell carcinoma (HNSCC) represents one of the most common cancers in humans. Close to 600,000 new diagnoses are made every year worldwide and over half of diagnosed patients will not survive. In view of this low survival rate, the development of novel cell-based assays for HNSCC will allow more mechanistic approaches for specific diagnostics for each individual patient. The cell-based assays will provide more informative data predicting cellular processes in treated patient, which in effect would improve patient follow up. More importantly, it will increase the specificity and effectiveness of therapeutic approaches. In this study, we investigated the role of serum from HNSCC patients on the regulation of microRNA (miRNA) expression in exposed cells in vitro. Next-generation sequencing of miRNA revealed that serum from HNSCC patients induced a different miRNA expression profile than the serum from healthy individuals. Out of 377 miRNA detected, we found that 16 miRNAs were differentially expressed when comparing cells exposed to serum from HNSCC or healthy individuals. The analysis of gene ontologies and pathway analysis revealed that these miRNA target genes were involved in biological cancer-related processes, including cell cycle and apoptosis. The real-time PCR analysis revealed that serum from HNSCC patients downregulate the expression level of five genes involved in carcinogenesis and two of these genes-P53 and SLC2A1 - are direct targets of detected miRNAs. These novel findings provide new insight into how cancer-associated factors in circulation regulate the expression of genes and regulatory elements in distal cells in favor of tumorigenesis. This has the potential for new therapeutic approaches and more specific diagnostics with tumor-specific cell lines or single-cell in vitro assays for personalized treatment and early detection of primary tumors or metastasis.

Keywords: head and neck squamous cell carcinomas, microRNA, sequencing data analysis, p53 pathway, cancerassociated factors 


\section{INTRODUCTION}

Head and neck squamous cell carcinomas (HNSCC) are squamous cell cancers originating in the lip and the oral cavity, oropharynx, hypopharynx, or larynx. The etiologies of HNSCC are divided into two groups corresponding to the two major risk factors for this type of cancer: (1) exposure to alcohol and tobacco and (2) infection with human papillomavirus (HPV).

Smoking increases the risk of HNSCC 5- to 25-fold (1) and the risk is even higher when habitual smoking and alcohol use are combined. Over the past decade, there has been a decrease in smoking- related HNSCC's cases. This is correlated with a decrease in the use of tobacco products. This decline is occurring congruently with an increase in HPV-positive HNSCC incidences, particularly in younger individuals (1-4).

MicroRNAs (miRNAs) are small, non-coding RNA molecules that are involved in gene regulation. After being transcribed, primary miRNA transcripts are processed into pre-miRNA hairpin structures before being cleaved into short, dsRNA fragments. Finally, one strand of the fragment is then degraded to form the mature miRNA (5). MiRNAs participate in the regulation of gene expression by forming RNA-induced silencing complexes that target complementary sequences on mRNA and either inhibit translation or cause degradation (6). Further, miRNAs can contribute to tumorigenesis either by upregulation of a miRNA targeting tumor suppressor genes or downregulation of a miRNA targeting oncogenes (7). For example, miR124a is frequently downregulated in several cancer types, including colon, breast, and lung carcinomas, as well as some leukemias and lymphomas. Because this miRNA is a negative regulator of CDK6, downregulation caused by hypermethylation results in increased levels of CDK6, which in turn facilitates inactivation of RB1 via phosphorylation (8). miRNAs have also been shown to regulate epigenetic processes by targeting DNMTs and histone methylating EZH2 complexes (9-11). Aberrant miRNA expression can result from chromosomal deletions, gene mutations involved in miRNA processing, or by epigenetic mechanisms that affect miRNA expression (12). DNA methylation and chromatin remodeling processes can cause dysregulation of miRNA in the same way as in gene encoding transcripts (13-15). This is evidenced by the ability of HDAC inhibitors $(16,17)$ and hypomethylating drugs (18) to induce changes in miRNA expression, suggesting interdependent regulation between these mechanisms.

Since serum samples are easily accessible in a clinical setting, they are often examined for the presence of biomarkers associated with various disease states. Studies have demonstrated that specific miRNA expression profiles can be identified between cancer tissue and adjacent healthy tissue in HNSCC patients (19). In our previous study, we also showed different expression levels between serum from HNSCC patients and serum from healthy individuals (20). There are also studies indicating alterations in miRNA levels when comparing serum from HNSCC patients before and after treatment (21). Further, several of these miRNAs have been shown to have diagnostic or prognostic value (22).

In vitro studies have demonstrated that serum from cancer patients generate tumorigenic phenotypes in cultured cells (23-25). This can occur by horizontal gene transfer from circulating, cell-free DNA $(25,26)$, or by the uptake of extracellular vesicles that are released into circulation by cancer cells (27-30). Extracellular vesicles, or exosomes, are membrane bound vesicles that may contain membrane or cytosolic proteins, lipids, or nucleic acids with roles in intercellular signaling (31). Released by both healthy and cancer cells, exosomes are found in many different body fluids, including urine, breast milk, blood, amniotic fluid, ascites, semen, and saliva $(27,31)$. Cancer cells use this mechanism to package and deliver oncogenic proteins $(32,33)$, mRNA, miRNA $(32,34,35)$, and DNA (28) This mechanism is capable of causing the malignant transformation of recipient cells, or it can facilitate cancer progression and metastasis (27).

In this study, we investigated the potential of serum from HNSCC patients to affect the regulation of miRNA expression in exposed cells, which could provide novel approaches in future diagnostic in vitro studies using a variety of well established and genetically characterized cell lines for HNSCC, as well as other types of cancer.

\section{MATERIALS AND METHODS}

\section{Human Blood Serum Collection}

Serum was collected and pre-processed in the Department of Head and Neck Surgery, Greater Poland Cancer Center before surgical treatment (Table 1). The Institutional Review Board of the University of Medical Sciences in Poznan approved the study, and both informed and written consents were obtained from all patients. Blood samples were collected in BD Vacutainer Serum Separation Tubes, incubated for $15 \mathrm{~min}$ at room temperature to allow coagulation, and centrifuged at $1,300 \mathrm{~g}$ for $10 \mathrm{~min}$. The serum supernatant was transferred to new tubes, centrifuged at $16,000 \mathrm{~g}$ for $15 \mathrm{~min}$ to remove any residual cells and debris, and stored at $-80^{\circ} \mathrm{C}(20)$.

\section{Cell Culture}

HeLa cells were grown in RPMI basal medium with L-glutamine and supplemented with $10 \% \mathrm{FBS}$ and $1 \%$ penicillin-streptomycin. Cells were grown in an incubator at $37^{\circ} \mathrm{C}$ at $5 \% \mathrm{CO}_{2}$.

\section{HNSCC Serum Treatments}

HeLa cells were plated in 24-well plate (Corning) at low density and allowed to attach for several hours. Medium was then removed and replaced with freshly prepared medium containing

\begin{tabular}{|c|c|c|c|c|}
\hline HNSCC patients & Age & TNM & Tumor grade & Tumor localization \\
\hline 1 & 60 & T3N2MO & G2 & Oropharynx \\
\hline 2 & 58 & T2N1M0 & G2 & Oral \\
\hline 3 & 55 & T4N2M0 & G2 & Larnyx \\
\hline 4 & 50 & T4N2MO & G2 & Larnyx \\
\hline 5 & 61 & T2N3M0 & G3 & Oral/oropharnyx \\
\hline 6 & 59 & T2NOMO & G1 & Oral \\
\hline
\end{tabular}


$10 \%$ human serum and no FBS. A total of 11 serum samples were used, 7 from HNSCC patients and 4 from healthy individuals. Cells were allowed to grow for $72 \mathrm{~h}$ before extracting RNA.

\section{MiRNA Extraction}

Total RNA was extracted from a confluent well of a 24-well plate of serum-treated cells $(n=11)$ using RNeasy Universal Plus Mini Kit (Qiagen) according to the manufacturer's instructions. RNA concentration and purity was determined using a plate reader (Epoch $^{\mathrm{TM}}$ Mircoplate Spectrophotometer, BioTek, Winooski, VT, USA).

\section{MiRNA Library Preparation and Sequencing}

Libraries for miRNA sequencing were prepared from RNA from serum and serum-treated cells using NEBNEXT Small RNA Library Prep Set for Illumina (New England Biolabs). Libraries were prepared according to the manufacturer's protocol, and each sample was given a unique index primer (a barcode). After that, libraries were size selected using a $6 \%$ polyacrylamide gel. The quantity and quality of miRNA libraries was determined using a BioAnalyzer and RNA Nano Lab Chip Kit (Agilent Technologies, Santa Clara, CA, USA). The barcoded samples were equimolarly combined in a single microcentrifuge tube and submitted to sequencing on a HiSeq 2500 instrument (Illumina Inc.). RNASeq data are available at the sequence read archive at NCBI under accession number SRP144712.

Sequencing data were analyzed using a sRNA toolbox (36) for alignment and quantification of miRNA libraries and EdgeR (37) was used for statistical analyses of differentially expressed miRNAs. MiRNAs with a FC $>1.3$ and FDR $<0.05$ were considered to be upregulated; and those with $\mathrm{FC}<0.70$ and FDR $<0.05$ were considered to be downregulated. Unsupervised hierarchical clustering was performed using the bioconductor package DESeq (1.2.0) and data for the 50 most expressed miRNAs was collected (38). MiRNA families were identified using miRBase (39). Analyses using $\mathrm{R}$ packages were implemented in the $\mathrm{R}$ (3.2.2) programming environment.

\section{Target and Pathway Analysis of miRNA-seq}

DIANA-mirPath (v.3) was used for gene ontology (GO) analysis of biological processes and KEGG molecular pathways $(40,41)$ using validated gene interactions of the differentially regulated miRNAs identified in Tarbase v7.0 database (42). $P$ values lower than 0.05 were considered significant for pathway and GO terms enrichment analyses. Only KEGG pathways with at least nine targeted genes targeted by at least six miRNAs were reported.

\section{Real-Time PCR}

Cells were seeded in 24-well plate in normal culture medium with FBS. After cells attached, media was removed and replaced with freshly prepared media supplemented with $10 \%$ human serum in place of FBS and allowed to grow for $72 \mathrm{~h}$. Cells were lifted and RNA was extracted using RNeasy Plus Universal Mini
Kit (Qiagen) according to kit manual. RNA concentration and purity was determined using a plate reader (Epoch ${ }^{\mathrm{TM}}$ Mircoplate Spectrophotometer, BioTek, Winooski, VT, USA).

RNA was converted to cDNA using iScript cDNA synthesis kit (Bio-Rad) according to the manufacturer protocol using $40 \mu \mathrm{L}$ reaction volumes. The cDNA was then diluted to $80 \mu \mathrm{L}$. Reactions were set up in a MicroAmp ${ }^{\circledR}$ Fast Optical 96-well reaction plate (Applied Biosystems) with $2 \mu \mathrm{L}$ of diluted cDNA, $0.2 \mu \mathrm{L}$ each of forward and reverse primer, $12.6 \mu \mathrm{L}$ of nuclease free water, and $5 \mu \mathrm{L}$ of Fast SYBR Green Master Mix (Applied Biosystems) per well. Quantitative real-time PCR (qPCR) was performed using a $7900 \mathrm{HT}$ Fast system (Applied Biosystems) at $95^{\circ} \mathrm{C}$ for $20 \mathrm{~s}$, followed by 45 cycles of $1 \mathrm{~s}$ denaturation at $95^{\circ} \mathrm{C}$ and $20 \mathrm{~s}$ annealing/extension at $62^{\circ} \mathrm{C}$. Primer sequences are listed in Table 2. Beta-2-microglobulin (B2M) was used as the housekeeping gene to normalize qPCR data. Relative gene expression in each sample was calculated using the following equation: $2^{\mathrm{A}-\mathrm{B}} / 2^{\mathrm{C}-\mathrm{D}}$ [A = Ct value of the gene of interest in the first control sample (cell line treated with serum from healthy human), $\mathrm{B}=\mathrm{Ct}$ value of the gene of interest in each sample, $\mathrm{C}=\mathrm{Ct}$ value of $\mathrm{B} 2 \mathrm{M}$ in the first control sample (cell line treated with serum from healthy human), and $\mathrm{D}=\mathrm{Ct}$ value of $\mathrm{B} 2 \mathrm{M}$ in each sample]. This gives the first control sample a relative expression of 1 and all other samples are calculated in relation to this sample. The results of the cells treated with serum from healthy individuals (control group) were averaged and results of all samples were divided by this average

TABLE 2 | List of primers used to determine relative gene expression.

\begin{tabular}{|c|c|c|}
\hline Gene & Primer & Sequence \\
\hline Beta-2-microglobulin (B2M) & $F^{\prime}$ & 5'-GAGTATGCCTGCCGTGTGAA-3' \\
\hline B2M & $\mathrm{R}^{\prime}$ & 5'-CGGCATCTTCAAACCTCCAT-3' \\
\hline TP53 & $\mathrm{F}^{\prime}$ & 5'-GTGCAGCTGTGGGTTGATTC-3' \\
\hline TP53 & $\mathrm{R}^{\prime}$ & 5'-GCCAGACCATCGCTATCTGA-3' \\
\hline RB1 & $F^{\prime}$ & 5'-TCAGAAGGTCTGCCAACACC-3' \\
\hline RB1 & $\mathrm{R}^{\prime}$ & 5'-CAGAAGTCCCGAATGATTCACC-3' \\
\hline CDC20 & $\mathrm{F}^{\prime}$ & 5'-AATGCGCCAGAGGGTTATCA-3' \\
\hline CDC20 & $\mathrm{R}^{\prime}$ & 5'-CGGCCAGTACATTCCCAGAA-3' \\
\hline SLC2A1 & $\mathrm{F}^{\prime}$ & 5'-GAACTCTTCAGCCAGGGTCC-3' \\
\hline SLC2A1 & $\mathrm{R}^{\prime}$ & 5'-ACCACACAGTTGCTCCACAT-3' \\
\hline DNMT1 & $F^{\prime}$ & 5'-GATCGAGACCACGGTTCCTC-3' \\
\hline DNMT1 & $\mathrm{R}^{\prime}$ & 5'-CGGCCTCGTCATAACTCTCC-3' \\
\hline DNMT3A & $\mathrm{F}^{\prime}$ & 5'-GGGGGAGGCACTTGACAC-3' \\
\hline DNMT3A & $\mathrm{R}^{\prime}$ & 5'-CTCTGTCAGCCTGTGGGTG-3' \\
\hline DNMT3B & $\mathrm{F}^{\prime}$ & 5'-ATAAGTCGAAGGTGCGTCGT-3' \\
\hline DNMT3B & $\mathrm{R}^{\prime}$ & 5'-TGTGCGTCTTCGAGTCTTGT-3' \\
\hline CDKN2A & $F^{\prime}$ & 5'-TGCCCAACGCACCGAAT-3' \\
\hline CDKN2A & $\mathrm{R}^{\prime}$ & 5'-CGGGTGAGAGTGGCGG-3' \\
\hline SMARCA4 & $\mathrm{F}^{\prime}$ & 5'-CGCAAGGAGGTGGACTACAG-3' \\
\hline SMARCA4 & $\mathrm{R}^{\prime}$ & 5'-AGCGTGCCCTCCTCGAT-3' \\
\hline CCND1 & $\mathrm{F}^{\prime}$ & 5'-GCCGAGAAGCTGTGCATC-3' \\
\hline CCND1 & $\mathrm{R}^{\prime}$ & 5'-GGCCAGGTTCCACTTGAG-3' \\
\hline GFP & $\mathrm{F}^{\prime}$ & 5'-GCTCGATGCGGTTCACCAG-3' \\
\hline GFP & $\mathrm{R}^{\prime}$ & 5'-GCTCGATGCGGTTCACCAG-3' \\
\hline HRAS & $F^{\prime}$ & 5'-GGACGAATACGACCCCACTAT-3' \\
\hline HRAS & $\mathrm{R}^{\prime}$ & 5'-TGTCCAACAGGCACGTCTC-3' \\
\hline NOTCH1 & $\mathrm{F}^{\prime}$ & 5'-AGCCTCAACGGGTACAAGTG-3' \\
\hline NOTHC1 & $\mathrm{R}^{\prime}$ & 5'-GCCACTGGTCATGTCTITGC-3' \\
\hline MDM2 & $F^{\prime}$ & 5'-AGGAGATाTGTाTGGCGTGC-3' \\
\hline MDM2 & $\mathrm{R}^{\prime}$ & 5'-TGAGTCCGATGATTCCTGCTG-3' \\
\hline PTEN & $F^{\prime}$ & 5'-ACTTGCAATCCTCAGTITGTGG-3' \\
\hline PTEN & $\mathrm{R}^{\prime}$ & 5'-AACTTGTCTTCCCGTCGTGT-3' \\
\hline
\end{tabular}


to express the fold change in expression of the genes of interest in relation to the average of the control group (cells treated with healthy human serum) (43).

\section{Statistical Analysis of Relative Gene Expression}

Relative expression of genes of interest for cells treated with serum from healthy or cancer patients were subjected to a twotailed $t$-test with a $95 \%$ confidence interval and graphed with mean \pm SEM using Prism 5 software (GraphPad).

\section{RESULTS}

\section{HNSCC Patient Serum Alters the miRNA Profile of Treated Cells}

In order to investigate the effects of cancer-associated circulating factors on cells in culture, we treated HeLa cells with serum from HNSCC patients and healthy donors. Next-generation sequencing of miRNA revealed that serum from HNSCC patients induced a different miRNA expression profile than the serum from healthy individuals. We detected a total of 377 miRNA expressed in HeLa cells and found a total of 16 miRNAs that were differentially expressed (Table 3): 12 were downregulated and 4 were upregulated.

\section{Key Pathways Are Targeted by Differentially Expressed miRNAs}

Tarbase did not contain interaction data for four of the differentially expressed miRNA that were identified, but analysis of the
GO (Table 4) and pathway targets (Table 5) of the 12 miRNA identified reveal that these miRNA target genes are involved in key biological processes. In addition to several targeted cancer pathways, other cancer-related processes, such as focal adhesion, cell cycle, and critical signaling pathways were identified. Among the top regulated Kegg pathways were pathways in cancer (Figure S1 in Supplementary Material), proteoglycans in cancer (Figure S2 in Supplementary Material), TGF- $\beta$ signaling pathways (Figure S3 in Supplementary Material), and FoxO signaling pathways (Figure S4 in Supplementary Material). A summary of the main target genes of the regulated miRNAs is provided in Figure 1. These data expose the potential ability of the serum from HNSCC patients to affect expression of genes in key cellular pathways by altering levels of regulating miRNAs.

\section{Other Critical Genes Are Affected by Exposure to Serum From Patients With HNSCC}

In order to relate the differentially expressed miRNA to gene expression, we performed quantitative PCR to measure mRNA levels of some critical genes involved in cancer and targeted by the differentially expressed miRNAs. A total of 14 genes were tested and 5 were found to have significantly reduced expressions $(p<0.05)$ in cells that were treated with serum from cancer patients compared with those treated with serum from healthy individuals (Figure 2). This further demonstrates the ability of HNSCC serum to alter the expression of cancer-related genes when introduced to cells.

TABLE 3 | List of microRNA (miRNA) differentially expressed between cells treated with head and neck squamous cell carcinomas (HNSCC) patient serum and with normal human serum.

\begin{tabular}{|c|c|c|c|c|c|}
\hline miRNA & Healthy ${ }^{a, b}$ & Cancer $^{\mathrm{a}, \mathrm{c}}$ & $\mathbf{F C}^{\mathbf{d}}$ & $P$-value & False discovery rate \\
\hline \multicolumn{6}{|l|}{ Downregulated } \\
\hline hsa-miR-216b-5pe & $1,945.6 \pm 753.8$ & $821.9 \pm 204.0$ & 0.42 & 0.0000 & 0.0000 \\
\hline hsa-miR-128-3pe & $6,633.9 \pm 762.8$ & $4,384.1 \pm 636.8$ & 0.66 & 0.0001 & 0.0049 \\
\hline hsa-miR-216a-3p & $317.0 \pm 130.3$ & $165.1 \pm 20.5$ & 0.52 & 0.0001 & 0.0049 \\
\hline hsa-miR-4443 & $50.9 \pm 25.6$ & $16.6 \pm 12.1$ & 0.33 & 0.0003 & 0.0206 \\
\hline hsa-miR-24-1-5p & $38.7 \pm 8.6$ & $20.7 \pm 4.9$ & 0.53 & 0.0005 & 0.0223 \\
\hline hsa-miR-212-5p & $225.6 \pm 44.9$ & $142.5 \pm 18.4$ & 0.63 & 0.0005 & 0.0225 \\
\hline hsa-miR-424-3p & $169.9 \pm 51.3$ & $104.1 \pm 13.0$ & 0.61 & 0.0010 & 0.0330 \\
\hline hsa-miR-4483 ${ }^{\circ}$ & $38.9 \pm 13.1$ & $19.5 \pm 6.0$ & 0.50 & 0.0009 & 0.0330 \\
\hline hsa-miR-132-5p & $557.4 \pm 61.2$ & $312.6 \pm 144.3$ & 0.56 & 0.0012 & 0.0353 \\
\hline hsa-miR-216a-5pe & $169.8 \pm 69.6$ & $88.1 \pm 34.3$ & 0.52 & 0.0016 & 0.0369 \\
\hline hsa-miR-32-5p & $607.1 \pm 71.7$ & $392.8 \pm 111.7$ & 0.65 & 0.0015 & 0.0369 \\
\hline hsa-miR-5100 & $400.9 \pm 74.8$ & $264.2 \pm 53.6$ & 0.66 & 0.0021 & 0.0465 \\
\hline \multicolumn{6}{|l|}{ Upregulated } \\
\hline hsa-miR-31-3p & $110.6 \pm 13.8$ & $246.9 \pm 92.1$ & 2.23 & 0.0000 & 0.0018 \\
\hline hsa-miR-143-5p & $1.1 \pm 1.1$ & $7.9 \pm 3.0$ & 5.81 & 0.0000 & 0.0025 \\
\hline hsa-miR-30c-2-3p & $709.6 \pm 51.0$ & $981.4 \pm 64.2$ & 1.38 & 0.0011 & 0.0348 \\
\hline hsa-miR-135b-5p & $4.5 \pm 2.6$ & $13.5 \pm 4.2$ & 3.03 & 0.0005 & 0.0223 \\
\hline
\end{tabular}

amiRNA reads per million.

${ }^{b}$ Cells treated with healthy human serum, $n=4$.

${ }^{\circ}$ Cells treated with HNSCC patient serum, $n=7$.

${ }^{d}$ Fold change in cancer serum compared with normal human serum.

eSeveral differentially expressed miRNAs were not found in Tarbase, so they were excluded from pathway analysis. 
TABLE 4 | Gene ontology terms for biological processes of target genes of 16 microRNAs (miRNAs) differentially expressed in cells treated with serum from healthy individuals compared with head and neck squamous cell carcinomas (HNSCC) patients.

\begin{tabular}{|c|c|c|c|}
\hline $\begin{array}{l}\text { Gene ontology category- } \\
\text { biological process }\end{array}$ & $P$-value & Genes $^{a}$ & miRNAs $^{b}$ \\
\hline Response to stress & $<3.33 E-16$ & 330 & 6 \\
\hline Catabolic process & $<3.33 E-16$ & 305 & 7 \\
\hline Viral process & $<3.33 \mathrm{E}-16$ & 124 & 7 \\
\hline $\begin{array}{l}\text { Symbiosis, encompassing } \\
\text { mutualism through parasitism }\end{array}$ & $<3.33 E-16$ & 138 & 7 \\
\hline Biological process & $<3.33 E-16$ & 2,006 & 8 \\
\hline Biosynthetic process & $<3.33 E-16$ & 665 & 8 \\
\hline $\begin{array}{l}\text { Cellular nitrogen compound } \\
\text { metabolic process }\end{array}$ & $<3.33 E-16$ & 813 & 8 \\
\hline Cellular protein modification process & $<3.33 E-16$ & 425 & 9 \\
\hline Gene expression & $<3.33 E-16$ & 171 & 9 \\
\hline Mitotic cell cycle & 3.33E-16 & 93 & 8 \\
\hline $\begin{array}{l}\text { Neurotrophin trk receptor } \\
\text { signaling pathway }\end{array}$ & $2.67 \mathrm{E}-13$ & 54 & 5 \\
\hline Cellular protein metabolic process & $3.89 \mathrm{E}-12$ & 80 & 5 \\
\hline Cellular component assembly & $1.44 \mathrm{E}-11$ & 184 & 5 \\
\hline MRNA metabolic process & $6.96 \mathrm{E}-11$ & 48 & 5 \\
\hline Small molecule metabolic process & $2.99 \mathrm{E}-10$ & 307 & 6 \\
\hline RNA metabolic process & $8.23 E-10$ & 53 & 5 \\
\hline Membrane organization & $4.12 \mathrm{E}-09$ & 98 & 5 \\
\hline Fc-epsilon receptor signaling pathway & $2.08 \mathrm{E}-08$ & 35 & 5 \\
\hline $\begin{array}{l}\text { Nucleobase-containing } \\
\text { compound catabolic process }\end{array}$ & 3.67E-08 & 128 & 5 \\
\hline Macromolecular complex assembly & 2.67E-07 & 122 & 5 \\
\hline DNA metabolic process & $3.81 \mathrm{E}-06$ & 87 & 2 \\
\hline $\begin{array}{l}\text { Epidermal growth factor } \\
\text { receptor signaling pathway }\end{array}$ & 5.96E-06 & 38 & 3 \\
\hline Transcription, DNA-templated & $1.18 \mathrm{E}-05$ & 286 & 3 \\
\hline Cell death & 2.68E-05 & 128 & 4 \\
\hline $\begin{array}{l}\text { Fibroblast growth factor } \\
\text { receptor signaling pathway }\end{array}$ & $5.45 E-05$ & 35 & 3 \\
\hline $\begin{array}{l}\text { Activation of signaling protein activity } \\
\text { involved in unfolded protein response }\end{array}$ & $3.01 \mathrm{E}-04$ & 17 & 4 \\
\hline Blood coagulation & $8.64 \mathrm{E}-04$ & 58 & 3 \\
\hline Viral life cycle & 5.31E-03 & 14 & 2 \\
\hline Immune system process & 7.60E-03 & 136 & 3 \\
\hline Protein complex assembly & 8.01E-03 & 82 & 3 \\
\hline $\begin{array}{l}\text { Endoplasmic reticulum } \\
\text { unfolded protein response }\end{array}$ & $8.49 \mathrm{E}-03$ & 18 & 2 \\
\hline Cellular lipid metabolic process & 1.69E-02 & 24 & 2 \\
\hline $\begin{array}{l}\text { Termination of RNA polymerase } \\
\text { to transcription }\end{array}$ & 2.33E-02 & 10 & 2 \\
\hline $\begin{array}{l}\text { TRIF-dependent toll-like } \\
\text { receptor signaling pathway }\end{array}$ & 2.91E-02 & 18 & 3 \\
\hline
\end{tabular}

${ }^{a}$ Number of genes in each process targeted by miRNAs.

${ }^{b}$ Number of miRNAs targeting genes in each process.

\section{DISCUSSION}

The miRNAs identified in the cells treated with the serum of HNSCC patients in this study interact with target mRNAs known to be involved in oncogenic processes, including proliferation, survival, and angiogenesis, and many have been shown to be dysregulated in cancer. Dysregulation of proteins involved in the regulation of apoptosis can have oncogenic consequences, as evidenced by the many cell cycle regulating proteins that are either tumor suppressors or oncogenes (44). One of these proteins that is frequently mutated or dysregulated in cancer is $\mathrm{p} 53$ This protein
TABLE 5 | KEGG pathways of target genes of 16 microRNAs (miRNAs) differentially expressed in cells treated with serum from healthy individuals compared with head and neck squamous cell carcinomas patients.

\begin{tabular}{|c|c|c|c|}
\hline KEGG pathway & $P$-value & Genes $^{\mathrm{a}}$ & miRNAs $^{b}$ \\
\hline Pathways in cancer & 1.23E-02 & 95 & 11 \\
\hline PI3K-AKT signaling pathway & 3.38E-02 & 82 & 12 \\
\hline HTLV-I infection & $3.24 \mathrm{E}-02$ & 68 & 12 \\
\hline Focal adhesion & 2.35E-03 & 62 & 11 \\
\hline Proteoglycans in cancer & $1.51 \mathrm{E}-06$ & 60 & 12 \\
\hline Epstein-Barr virus infection & 9.00E-03 & 58 & 12 \\
\hline Viral carcinogenesis & $1.80 \mathrm{E}-03$ & 56 & 11 \\
\hline Endocytosis & $2.51 \mathrm{E}-02$ & 52 & 11 \\
\hline FOXO signaling pathway & $2.35 \mathrm{E}-03$ & 46 & 11 \\
\hline Hepatitis B & 3.62E-03 & 46 & 12 \\
\hline $\begin{array}{l}\text { Protein processing in } \\
\text { endoplasmic reticulum }\end{array}$ & $2.51 \mathrm{E}-02$ & 45 & 10 \\
\hline RNA transport & 4.32E-02 & 44 & 11 \\
\hline Ubiquitin-mediated proteolysis & $2.48 \mathrm{E}-02$ & 41 & 10 \\
\hline Cell cycle & $2.35 \mathrm{E}-03$ & 40 & 10 \\
\hline Transcriptional misregulation in cancer & 4.32E-02 & 40 & 10 \\
\hline $\begin{array}{l}\text { Signaling pathways regulating } \\
\text { pluripotency of stem cells }\end{array}$ & 3.43E-02 & 39 & 11 \\
\hline Thyroid hormone signaling pathway & 8.07E-03 & 37 & 11 \\
\hline Neurotrophin signaling pathway & $1.38 \mathrm{E}-02$ & 36 & 11 \\
\hline AMPK signaling pathway & 4.32E-02 & 36 & 11 \\
\hline Oocyte meiosis & 1.69E-04 & 35 & 10 \\
\hline Small cell lung cancer & 4.01E-04 & 33 & 10 \\
\hline Choline metabolism in cancer & 5.34E-03 & 33 & 10 \\
\hline Prostate cancer & $2.35 \mathrm{E}-03$ & 32 & 11 \\
\hline Adherens junction & 7.74E-07 & 30 & 10 \\
\hline Estrogen signaling pathway & $3.62 \mathrm{E}-03$ & 30 & 11 \\
\hline Bacterial invasion of epithelial cells & 9.64E-05 & 29 & 10 \\
\hline Erbb signaling pathway & 1.62E-02 & 29 & 9 \\
\hline Chronic myeloid leukemia & 4.96E-04 & 28 & 10 \\
\hline Progesterone-mediated oocyte maturation & $3.28 \mathrm{E}-02$ & 28 & 12 \\
\hline Salmonella infection & 4.05E-02 & 27 & 11 \\
\hline Glioma & 3.37E-06 & 26 & 9 \\
\hline Colorectal cancer & 6.49E-05 & 26 & 11 \\
\hline Apoptosis & 7.44E-03 & 24 & 9 \\
\hline P53 signaling pathway & $9.00 \mathrm{E}-03$ & 24 & 10 \\
\hline Prolactin signaling pathway & 9.00E-03 & 24 & 10 \\
\hline Non-small cell lung cancer & 1.69E-04 & 23 & 10 \\
\hline Shigellosis & $2.35 \mathrm{E}-03$ & 23 & 10 \\
\hline Pancreatic cancer & $3.42 \mathrm{E}-03$ & 23 & 9 \\
\hline Renal cell carcinoma & 3.50E-02 & 22 & 8 \\
\hline $\begin{array}{l}\text { Epithelial cell signaling in } \\
\text { helicobacter pylori infection }\end{array}$ & 4.62E-02 & 22 & 7 \\
\hline Melanoma & 2.96E-02 & 21 & 8 \\
\hline Endometrial cancer & $2.35 \mathrm{E}-03$ & 20 & 11 \\
\hline Central carbon metabolism in cancer & $3.24 \mathrm{E}-02$ & 20 & 8 \\
\hline Synaptic vesicle cycle & 3.38E-02 & 18 & 7 \\
\hline Bladder cancer & 1.61E-02 & 15 & 7 \\
\hline Lysine degradation & 3.38E-02 & 12 & 6 \\
\hline Thyroid cancer & 5.23E-03 & 11 & 7 \\
\hline Fatty acid metabolism & $5.16 \mathrm{E}-03$ & 9 & 9 \\
\hline
\end{tabular}

${ }^{a}$ Number of genes in each pathway targeted by miRNAs.

${ }^{b}$ Number of miRNAs targeting genes in each pathway.

acts as a guardian of the DNA damage cell cycle checkpoint and is responsible for initiating apoptosis when damage is repaired (44). The tumor suppressor gene, p53, plays a major role in a variety of cancers, including head and neck (45).

In this study, we identified MDM2 as a target of miR$32-5 \mathrm{p}$, which we found to be downregulated in cells treated with HNSCC serum compared with those treated with serum 
from healthy donors. This interaction is supported by studies demonstrating the ability of miR-32 to cause accumulation of the tumor suppressor $\mathrm{p} 53$ by facilitating degradation of MDM2 (46). Importantly, our additional analysis of previously published studies of serum-circulating miRNA conducted in our laboratory (20) - as well as miRNA differentially regulated in cells treated with serum from HNSCC patients in this study-indicated that miR-32-5p represents the single common miRNA differentially regulated in the circulation of HNSCC patients, and also in cells treated with serum from HNSCC patients. Further, Sirt1, a target of differentially expressed miR-128-3p and miR-32-5p, also deacetylates p53, thereby inhibiting its transcriptional activity (47). Thus, reduced expression of these miRNA could facilitate p53 inhibition in the treated cells by increasing Sirt1 expression. Notably, we also found that exposure to serum from HNSCC patients resulted in decreased $\mathrm{p} 53$ expression.

Two other miRNAs found in this study to be downregulated by exposure to the HNSCC patient serum, namely miR-212-5p and miR-132-5p, also target proteins involved in cell cycle regulation. MiR-212-5p targets CCND1 and miR-132-5p targets $\mathrm{Bcl} 2$. The protein product of CCND1, cyclin D1, cooperates with other proteins and will facilitate cell cycle progression from G1 to $S$ phase (48), while $\mathrm{Bcl} 2$ inhibits apoptosis by blocking the activity of pro-apoptotic proteins like Bax, Bak, and p53 (49). MiR-132 and miR-212 are formed by differential processing of the same primary miRNA. Upregulation of this gene cluster was shown to increase apoptosis and downregulate cyclin D1 and induce cell cycle arrest (50).

Mir-31 has been shown to have oncogenic influence (51) and the potential as a biomarker for detection and to monitor treatment response and prognosis (52-55). Along with miR135b-5p, miR-31-3p has also been shown by our lab to be upregulated in tumor tissue of HNSCC patients compared with adjacent normal tissue (56). Both miR-31-3p and miR-135b-5p were found to be upregulated in cells treated with serum from cancer patients in this study.

Mir-128 has been shown to be downregulated in many types of cancer and acts as a tumor suppressor in HNSCC specifically. Overexpression of miR-128 in HNSCC cell lines inhibited cell growth and downregulated anti-apoptotic proteins, including MDM2, Bcl2, and NFkB (57). MCL1, another anti-apoptotic member of the BCL2 family, is a target of miR-32-5p, and overexpression of miR-32 was shown to induce apoptosis (58). MiR-135-5p, one of the miRNAs found to be upregulated in cells treated with serum from HNSCC patients, targets the tumor suppressor APC and promotes cell growth in colorectal cancer (59).

We found that SLC2A1, a target of miR-30c-2-3p, was downregulated in cells treated with cancer serum but not with normal serum. Although the other downregulated genes identified in this study were not identified as direct targets of the differentially expressed miRNA, they could be indirectly affected by other genes that are targeted. Several of the miRNAs identified target genes involved in regulating gene expression, such as transcription factors and histone modifiers, potentially enable them to pleiotropically alter gene expression in the treated cells.

In summary, 16 miRNAs were found to be differentially expressed in cells treated with serum from HNSCC patients compared with cells treated with serum from healthy humans. These miRNAs are involved in essential cellular processes that

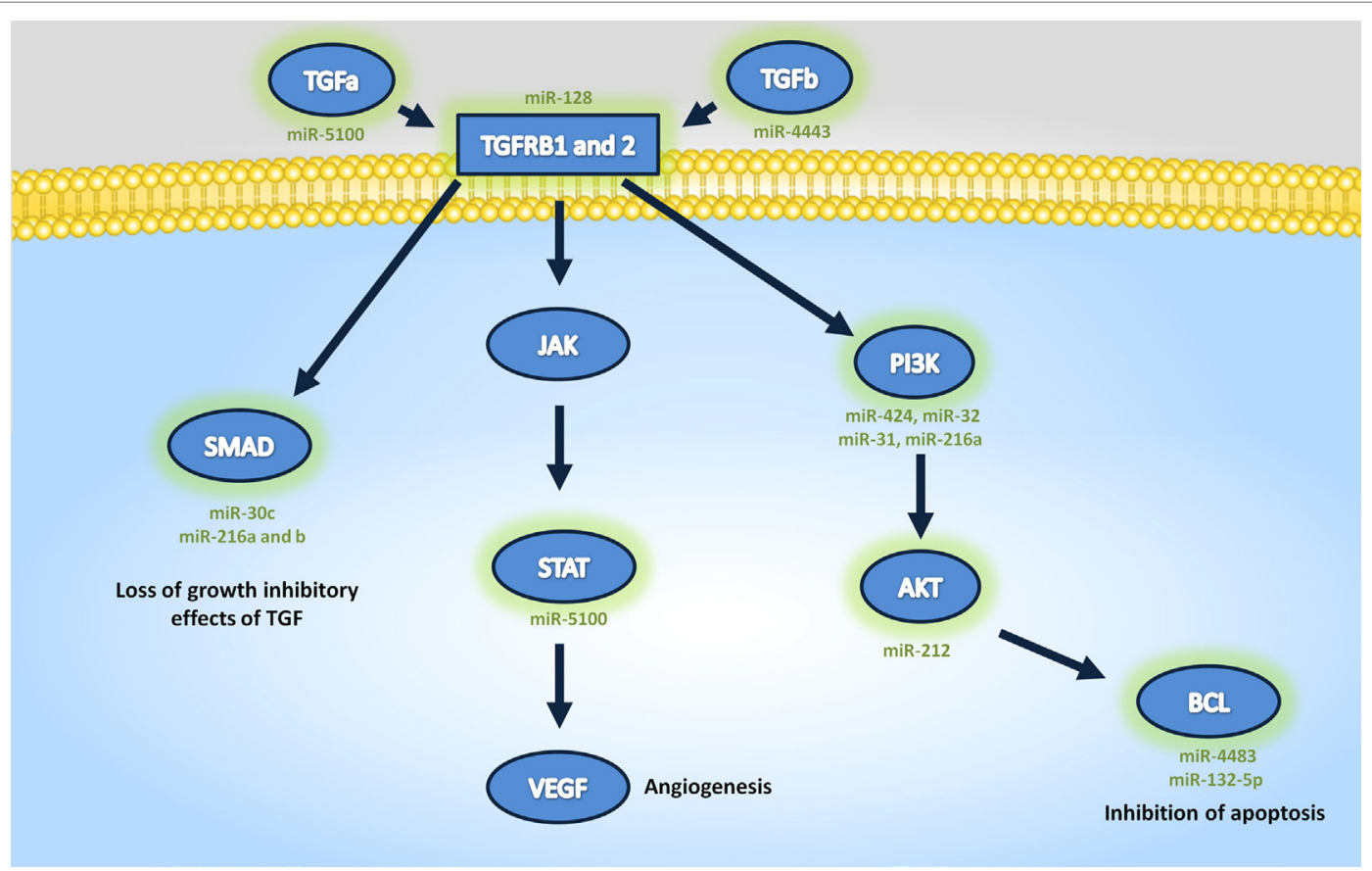

FIGURE 1 | Summary of the main target genes targeted regulated microRNAs. 

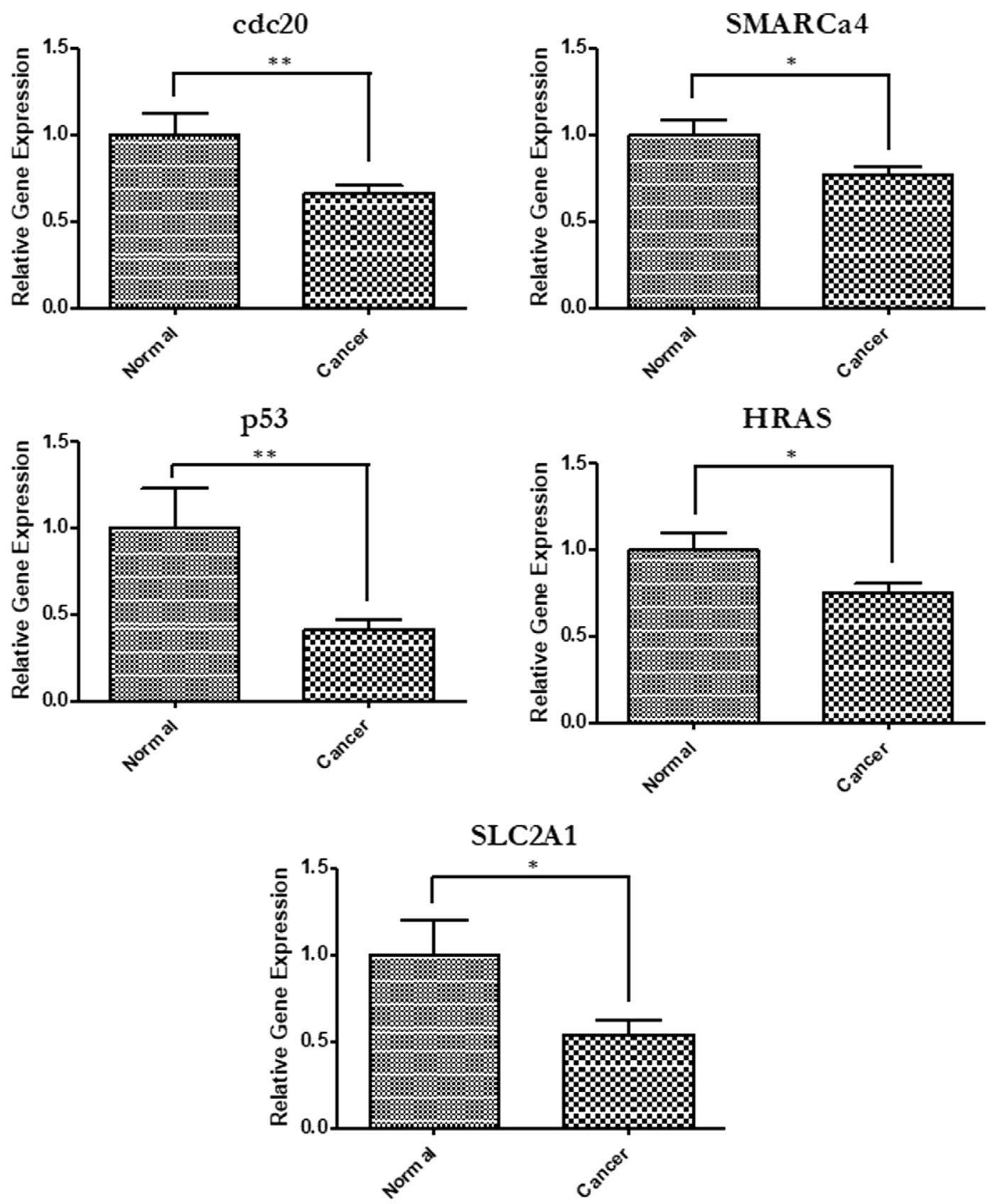

FIGURE 2 | Gene expression changes in cells exposed to head and neck squamous cell carcinomas patient serum. Quantitative PCR was used to determine relative gene expression of several cancer-related genes. Primers used for each analysis are listed in Table 2. SLC2a1 ( $p=0.0198$ ), $p 53$ ( $p=0.0011)$, cdc20 $(p=0.0043)$, HRAS $(p=0.0306)$, and Smarca4 $(p=0.0235)$.

are dysregulated in cancer cells. Further, the serum altered the expression of several cancer-related genes. While other studies have demonstrated differences in miRNA expression between healthy and cancer tissue in HNSCC, as well as in the circulation of HNSCC patients, this study goes further to demonstrate the ability of serum from cancer patients to alter the expression of both genes and miRNAs in exposed cells. This concept could have a significant impact on the study of metastatic cancer as it reveals the ability of cancer-associated factors in circulation to affect the expression of genes and regulatory elements in distal cells in favor of tumorigenesis. This could also contribute to the systemic effects that cancer has on patient health. Further, better understanding of the role of serum associated factors on the regulation of tumorigenesis can lead to new therapeutic approaches. More importantly, these findings can help to develop new diagnostics using established tumor-specific cell lines or single-cell in vitro assays for personalized treatments and non-invasive follow-ups after surgical and oncological treatment. 


\section{ETHICS STATEMENT}

All methods in this study followed the protocol approved by the Institutional Review Board of Poznan University of Medical Sciences in Poznan, Poland. All experiments were performed in accordance with relevant guidelines and regulations. Informed consent for participation in the study has been obtained from all patients included in the study in accordance with the Declaration of Helsinki.

\section{AUTHOR CONTRIBUTIONS}

BA designed the study, performed experiments, and wrote the manuscript. AS analyzed the data, prepared the figures, and wrote the manuscript. BV performed experiments. YL analyzed the data, performed statistical analysis. MM designed experiments, prepared the manuscript. MS, JP, and EM gathered and provided patients data, reviewed the manuscript. WB gathered and provided patient data, processed the blood samples. WG obtained the tissue specimens during the surgical procedure. PG designed the study, obtained the tissue specimens during surgical procedures, selected the patients, and wrote the manuscript. MM designed the study, wrote the manuscript, and supervised the experiments.

\section{REFERENCES}

1. Marur S, Forastiere AA. Head and neck cancer: changing epidemiology, diagnosis, and treatment. Mayo Clin Proc (2008) 83:489-501. doi:10.4065/83.4.489

2. Sturgis EM, Cinciripini PM. Trends in head and neck cancer incidence in relation to smoking prevalence. Cancer (2007) 110:1429-35. doi:10.1002/ cncr. 22963

3. Marur S, Forastiere AA. Head and neck squamous cell carcinoma: update on epidemiology, diagnosis, and treatment. Mayo Clinic Proc (2016) 91:386-96. doi:10.1016/j.mayocp.2015.12.017

4. Vigneswaran N, Williams MD. Epidemiological trends in head and neck cancer and aids in diagnosis. Oral Maxillofac Surg Clin North Am (2014) 26:123-41. doi:10.1016/j.coms.2014.01.001

5. Bartel DP. MicroRNAs: genomics, biogenesis, mechanism, and function. Cell (2004) 116:281-97. doi:10.1016/S0092-8674(04)00045-5

6. Cuellar TL, McManus MT. MicroRNAs and endocrine biology. J Endocrinol (2005) 187:327-32. doi:10.1677/joe.1.06426

7. MacFarlane L-A, Murphy PR. MicroRNA: biogenesis, function and role in cancer. Curr Genomics (2010) 11:537-61. doi:10.2174/ 138920210793175895

8. Lujambio A, Ropero S, Ballestar E, Fraga MF, Cerrato C, Setién F, et al. Genetic unmasking of an epigenetically silenced microRNA in human cancer cells. Cancer Res (2007) 67:1424. doi:10.1158/0008-5472.CAN-06-4218

9. Fabbri M, Garzon R, Cimmino A, Liu Z, Zanesi N, Callegari E, et al. MicroRNA-29 family reverts aberrant methylation in lung cancer by targeting DNA methyltransferases 3A and 3B. Proc Natl Acad Sci U S A (2007) 104:15805-10. doi:10.1073/pnas.0707628104

10. Friedman JM, Liang G, Liu CC, Wolff EM, Tsai YC, Ye W, et al. The putative tumor suppressor microRNA-101 modulates the cancer epigenome by repressing the polycomb group protein EZH2. Cancer Res (2009) 69:2623-9. doi:10.1158/0008-5472.CAN-08-3114

11. Leuenberger C, Schuoler C, Bye H, Mignan C, Rechsteiner T, Hillinger S, et al. MicroRNA-223 controls the expression of histone deacetylase 2: a novel axis in COPD. J Mol Med (2016) 94:725-34. doi:10.1007/s00109016-1388-1

12. Suzuki H, Maruyama R, Yamamoto E, Kai M. Epigenetic alteration and microRNA dysregulation in cancer. Front Genet (2013) 4:258. doi:10.3389/ fgene.2013.00258

\section{ACKNOWLEDGMENTS}

We would like to thank James Holland (College of Medicine, University of Central Florida) for editing the manuscript.

\section{SUPPLEMENTARY MATERIAL}

The Supplementary Material for this article can be found online at https://www.frontiersin.org/articles/10.3389/fonc.2018.00217/ full\#supplementary-material.

FIGURE S1 | KEGG pathway (40) analysis: pathways in cancer. Diagram of pathways in cancer genes and interactions. Genes highlighted in yellow are targeted by one of the differently expressed microRNA (miRNA) and genes highlighted in orange are targeted by more than one miRNA.

FIGURE S2 | KEGG pathway (40) analysis: proteoglycans in cancer. Diagram of pathways in cancer genes and interactions. Genes highlighted in yellow are targeted by one of the differently expressed microRNA (miRNA) and genes highlighted in orange are targeted by more than one miRNA.

FIGURE S3 | KEGG pathway (40) analysis: TGF- $\beta$ signaling pathways. Diagram of pathways in cancer genes and interactions. Genes highlighted in yellow are targeted by one of the differently expressed microRNA (miRNA) and genes highlighted in orange are targeted by more than one miRNA.

FIGURE S4 | KEGG pathway (40) analysis: FoxO signaling pathway. Diagram of pathways in cancer genes and interactions. Genes highlighted in yellow are targeted by one of the differently expressed microRNA (miRNA) and genes highlighted in orange are targeted by more than one miRNA.

13. Cimmino A, Calin GA, Fabbri M, Iorio MV, Ferracin M, Shimizu M, et al. miR-15 and miR-16 induce apoptosis by targeting BCL2. Proc Natl Acad Sci US A (2005) 102:13944-9. doi:10.1073/pnas.0506654102

14. Johnson SM, Grosshans H, Shingara J, Byrom M, Jarvis R, Cheng A, et al. RAS is regulated by the let-7 MicroRNA family. Cell (2005) 120:635-47. doi:10.1016/j.cell.2005.01.014

15. Saito Y, Liang G, Egger G, Friedman JM, Chuang JC, Coetzee GA, et al. Specific activation of microRNA-127 with downregulation of the protooncogene BCL6 by chromatin-modifying drugs in human cancer cells. Cancer Cell (2006) 9:435-43. doi:10.1016/j.ccr.2006.04.020

16. Scott GK, Mattie MD, Berger CE, Benz SC, Benz CC. Rapid alteration of microRNA levels by histone deacetylase inhibition. Cancer Res (2006) 66:1277-81. doi:10.1158/0008-5472.CAN-05-3632

17. Lee EM, Shin S, Cha HJ, Yoon Y, Bae S, Jung JH, et al. Suberoylanilide hydroxamic acid (SAHA) changes microRNA expression profiles in A549 human non-small cell lung cancer cells. Int J Mol Med (2009) 24:45-50. doi:10.3892/ijmm_00000204

18. Zhou Q, Long L, Zhou T, Tian J, Zhou B. Demethylation of microRNA-124a genes attenuated proliferation of rheumatoid arthritis derived fibroblastlike synoviocytes and synthesis of tumor necrosis factor-alpha. PLoS One (2016) 11:e0164207. doi:10.1371/journal.pone.0164207

19. Ramdas L, Giri U, Ashorn C, Coombes KR, el-Naggar A, Ang KK, et al. miRNA expression profiles in head and neck squamous cell carcinoma and adjacent normal tissue. Head Neck (2009) 31:642-54. doi:10.1002/hed.21017

20. Martinez BV,DhahbiJM,Lopez YON,LamperskaK, Golusinski P, LuczewskiL, et al. Circulating small non coding RNA signature in head and neck squamous cell carcinoma. Oncotarget (2015) 6:19246-63. doi:10.18632/ oncotarget. 4266

21. Summerer I, Unger K, Braselmann H, Schuettrumpf L, Maihoefer C, Baumeister $\mathrm{P}$, et al. Circulating microRNAs as prognostic therapy biomarkers in head and neck cancer patients. Br J Cancer (2015) 113:76-82. doi:10.1038/ bjc.2015.111

22. Wong N, Khwaja SS, Baker CM, Gay HA, Thorstad WL, Daly MD, et al. Prognostic microRNA signatures derived from the Cancer Genome Atlas for head and neck squamous cell carcinomas. Cancer Med (2016) 5:1619-28. doi:10.1002/cam4.718

23. Abdouh M, Zhou S, Arena V, Arena M, Lazaris A, Onerheim R, et al. Transfer of malignant trait to immortalized human cells following exposure 
to human cancer serum. J Exp Clin Cancer Res (2014) 33:86. doi:10.1186/ s13046-014-0086-5

24. Hamam D, Abdouh M, Gao Z-H, Arena V, Arena M, Arena GO. Transfer of malignant trait to BRCA1 deficient human fibroblasts following exposure to serum of cancer patients. J Exp Clin Cancer Res (2016) 35:80. doi:10.1186/ s13046-016-0360-9

25. Trejo-Becerril C, Pérez-Cárdenas E, Taja-Chayeb L, Anker P, HerreraGoepfert R, Medina-Velázquez LA, et al. Cancer progression mediated by horizontal gene transfer in an in vivo model. PLoS One (2012) 7:e52754. doi:10.1371/journal.pone.0052754

26. García-Olmo DC, Domínguez C, García-Arranz M, Anker P, Stroun M, García-Verdugo JM, et al. Cell-free nucleic acids circulating in the plasma of colorectal cancer patients induce the oncogenic transformation of susceptible cultured cells. Cancer Res (2010) 70:560. doi:10.1158/0008-5472. CAN-09-3513

27. Ogorevc E, Kralj-Iglic V, Veranic P. The role of extracellular vesicles in phenotypic cancer transformation. Radiol Oncol (2013) 47:197-205. doi:10.2478/ raon-2013-0037

28. Balaj L, Lessard R, Dai L, Cho Y-J, Pomeroy SL, Breakefield XO, et al. Tumour microvesicles contain retrotransposon elements and amplified oncogene sequences. Nat Commun (2011) 2:180. doi:10.1038/ncomms1180

29. Abd Elmageed ZY, Yang Y, Thomas R, Ranjan M, Mondal D, Moroz K, et al. Neoplastic reprogramming of patient-derived adipose stem cells by prostate cancer cell-associated exosomes. Stem Cells (2014) 32:983-97. doi:10.1002/ stem.1619

30. Peinado H, Aleckovic M, Lavotshkin S, Matei I, Costa-Silva B, Moreno-Bueno G, et al. Melanoma exosomes educate bone marrow progenitor cells toward a pro-metastatic phenotype through MET. Nat Med (2012) 18:883-91. doi: $10.1038 / \mathrm{nm} .2753$

31. Raposo G, Stoorvogel W. Extracellular vesicles: exosomes, microvesicles, and friends. J Cell Biol (2013) 200:373. doi:10.1083/jcb.201211138

32. Skog J, Wurdinger T, van Rijn S, Meijer DH, Sena-Esteves M, Gainche L, et al. Glioblastoma microvesicles transport RNA and proteins that promote tumour growth and provide diagnostic biomarkers. Nat Cell Biol (2008) 10:1470-6. doi:10.1038/ncb1800

33. Runz S, Keller S, Rupp C, Stoeck A, Issa Y, Koensgen D, et al. Malignant ascites-derived exosomes of ovarian carcinoma patients contain CD24 and EpCAM. Gynecologic Oncol (2007) 107:563-71. doi:10.1016/j.ygyno.2007. 08.064

34. Grange C, Tapparo M, Collino F, Vitillo L, Damasco C, Deregibus MC, et al. Microvesicles released from human renal cancer stem cells stimulate angiogenesis and formation of lung premetastatic niche. Cancer Res (2011) 71:5346. doi:10.1158/0008-5472.CAN-11-0241

35. Valadi H, Ekstrom K, Bossios A, Sjostrand M, Lee JJ, Lotvall JO. Exosomemediated transfer of mRNAs and microRNAs is a novel mechanism of genetic exchange between cells. Nat Cell Biol (2007) 9:654-9. doi:10.1038/ ncb1596

36. Rueda A, Barturen G, Lebron R, Gomez-Martin C, Alganza A, Oliver JL, et al. sRNAtoolbox: an integrated collection of small RNA research tools. Nucleic Acids Res (2015) 43:W467-73. doi:10.1093/nar/gkv555

37. Robinson MD, McCarthy DJ, Smyth GK. edgeR: a Bioconductor package for differential expression analysis of digital gene expression data. Bioinformatics (2010) 26:139-40. doi:10.1093/bioinformatics/btp616

38. Anders S, Huber W. Differential expression analysis for sequence count data. Genome Biol (2010) 11:R106. doi:10.1186/gb-2010-11-10-r106

39. Kozomara A, Griffiths-Jones S. miRBase: integrating microRNA annotation and deep-sequencing data. Nucleic Acids Res (2011) 39:D152-7. doi:10.1093/ nar/gkq1027

40. Kanehisa M, Goto S. KEGG: kyoto encyclopedia of genes and genomes. Nucleic Acids Res (2000) 28:27-30. doi:10.1093/nar/28.1.27

41. Kanehisa M, Sato Y, Kawashima M, Furumichi M, Tanabe M. KEGG as a reference resource for gene and protein annotation. Nucleic Acids Res (2016) 44:D457-62. doi:10.1093/nar/gkv1070

42. Vlachos IS, Zagganas K, Paraskevopoulou MD, Georgakilas G, Karagkouni D, Vergoulis T, et al. DIANA-miRPath v3.0: deciphering microRNA function with experimental support. Nucleic Acids Res (2015) 43:W460-6. doi:10.1093/ nar/gkv403
43. Louis A, Bartke A, Masternak MM. Effects of growth hormone and thyroxine replacement therapy on insulin signaling in ames dwarf mice. J Gerontol A Biol Sci Med Sci (2010) 65:344-52. doi:10.1093/gerona/glq018

44. Canman CE, Kastan MB. Induction of apoptosis by tumor suppressor genes and oncogenes. Semin Cancer Biol (1995) 6:17-25. doi:10.1006/scbi.1995.0003

45. Denaro N, Lo Nigro C, Natoli G, Russi EG, Adamo V, Merlano MC. The role of p53 and MDM2 in head and neck cancer. ISRN Otolaryngol (2011) 2011:931813. doi:10.5402/2011/931813

46. Suh S-S, Yoo JY, Nuovo GJ, Jeon Y-J, Kim S, Lee TJ, et al. MicroRNAs/ TP53 feedback circuitry in glioblastoma multiforme. Proc Natl Acad Sci U S A (2012) 109:5316-21. doi:10.1073/pnas.1202465109

47. Yi J, Luo J. SIRT1 and p53, effect on cancer, senescence and beyond. Biochim Biophys Acta (2010) 1804:1684-9. doi:10.1016/j.bbapap.2010.05.002

48. O'Leary NA, Wright MW, Brister JR, Ciufo S, Haddad D, McVeigh R, et al. Reference sequence (RefSeq) database at NCBI: current status, taxonomic expansion, and functional annotation. Nucleic Acids Res (2016) 44:D733-45. doi:10.1093/nar/gkv1189

49. Westphal D, Dewson G, Czabotar PE, Kluck RM. Molecular biology of Bax and Bak activation and action. Biochim Biophys Acta (2011) 1813:521-31. doi:10.1016/j.bbamcr.2010.12.019

50. Jiang X, Chen X, Chen L, Ma Y, Zhou L, Qi Q, et al. Upregulation of the miR212/132 cluster suppresses proliferation of human lung cancer cells. Oncol Rep (2015) 33:705-12. doi:10.3892/or.2014.3637

51. Zheng W, Liu Z, Zhang W, Hu X. miR-31 functions as an oncogene in cervical cancer. Arch Gynecol Obstet (2015) 292:1083-9. doi:10.1007/ s00404-015-3713-2

52. Ma Y, Chen Y, Lin J, Liu Y, Luo K, Cao Y, et al. Circulating miR-31 as an effective biomarker for detection and prognosis of human cancer: a meta-analysis. Oncotarget (2017) 8:28660-71. doi:10.18632/oncotarget.15638

53. Yan HJ, Ma JY, Wang L, Gu W. Expression and significance of circulating microRNA-31 in lung cancer patients. Med Sci Monit (2015) 21:722-6. doi:10.12659/MSM.893213

54. Zhang T, Wang Q, Zhao D, Cui Y, Cao B, Guo L, et al. The oncogenetic role of microRNA-31 as a potential biomarker in oesophageal squamous cell carcinoma. Clin Sci (Lond) (2011) 121:437-47. doi:10.1042/CS20110207

55. Nunez Lopez YO, Victoria B, Golusinski P, Golusinski W, Masternak MM. Characteristic miRNA expression signature and random forest survival analysis identify potential cancer-driving miRNAs in a broad range of head and neck squamous cell carcinoma subtypes. Rep Pract Oncol Radiother (2018) 23:6-20. doi:10.1016/j.rpor.2017.10.003

56. Schneider A, Victoria B, Lopez YN, Suchorska W, Barczak W, Sobecka A, et al. Tissue and serum microRNA profile of oral squamous cell carcinoma patients. Sci Rep (2018) 8:675. doi:10.1038/s41598-017-18945-Z

57. Hauser B, Zhao Y, Pang X, Ling Z, Myers E, Wang P, et al. Functions of MiRNA128 on the regulation of head and neck squamous cell carcinoma growth and apoptosis. PLoS One (2015) 10:e0116321. doi:10.1371/journal.pone.0116321

58. Mishra PJ, Mishra PJ, Merlino G. Integrated genomics identifies miR-32/ MCL-1 pathway as a critical driver of melanomagenesis: implications for miR-replacement and combination therapy. PLoS One (2016) 11:e0165102. doi:10.1371/journal.pone.0165102

59. Valeri N, Braconi C, Gasparini P, Murgia C, Lampis A, Paulus-Hock V, et al. MicroRNA-135b promotes cancer progression by acting as a downstream effector of oncogenic pathways in colon cancer. Cancer Cell (2014) 25:469-83. doi:10.1016/j.ccr.2014.03.006

Conflict of Interest Statement: The authors declare that the research was conducted in the absence of any commercial or financial relationships that could be construed as a potential conflict of interest.

Copyright (c) 2018 Allen, Schneider, Victoria, Nunez Lopez, Muller, Szewczyk, Pazdrowski, Majchrzak, Barczak, Golusinski, Golusinski and Masternak. This is an open-access article distributed under the terms of the Creative Commons Attribution License (CC BY). The use, distribution or reproduction in other forums is permitted, provided the original author(s) and the copyright owner are credited and that the original publication in this journal is cited, in accordance with accepted academic practice. No use, distribution or reproduction is permitted which does not comply with these terms. 